physical, mental and spiritual deformation consequent on modern industrialism must be guided and controlled by an inspired rationalism. The scientist must take the lead, and turn the present chaos of conflicting speculations about physical education into a cosmos of orderly teaching and practice." It is to be hoped that Dr. Griffin's readers generally will be more fortunate than the reviewer in their attempt to understand what that means.

\section{MODERN TREATMENT IN GENERAL PRACTICE.}

\section{Vol. III.}

Edited by Cecil P. G. Wakeley, D.Sc., F.R.C.S., F.R.S.E. 436 pp., 54 figs. The Medical Press \& Circular, London. 1937. Price $10 / 6$ net.

This third volume of Modern Treatment contains fifty-one articles by as many writers of distinction on as many subjects. One is struck by the frankness and directness of many of the articles, especially on surgical subjects. Only men of great experience and courage could write these revelations of things as they are and point the moral. The articles on the treatment of hare lip, and the diagnosis and treatment of fistulain-ano are very illuminating as to anatomy and method compared with a generation ago. In the article on breast cancer and its treatment by radium a plea is put forward for every district to have its cancer hospital, just as it has its asylum, tuberculosis hospital, and infectious diseases hospital. In all there are six articles on cancer treatments.

It is refreshing to read under chronic bronchitis, "It has long been a habit of mine to advise chronic bronchitics dwelling in town to close their bedroom windows on cold, damp, and foggy nights" and "In the more advanced cases, this practice may have to be extended ..." There follows valuable advices on drug treatments. The value of a compressed-air chamber in emphysema is recognized and explained and substitutes described and objections met.

Behaviour disorders in children and psychological problems in childhood, organic aspects of psychiatry, and psychiatry and general practice are also dealt with concisely. And many others, including injuries about the wrist-joint, and industrial injuries of the hand and foot.
In an article on dietetic essentials in general practice the following statement occurs, which is contrary to historical facts in regard to adenoids and rickets at any rate:"It is important to remember this (heat coagulates some of the constituents of milk, notably albumen; it kills the friendly bacteria, and drives off the vitamins and enzymes), because in the pre-vitamin days, when the microbe dominated not only the surgery but the kitchen, it was an unchallenged axiom that all milk, and nearly all other foods, should be, ought to be, must be, cooked. And they were ; with the result that adenoids, appendicitis, rickets and various other deficiency diseases filled the wards and out-patient rooms of the hospitals, breeding criminals, pansies, and village idiots ...." After having been brought up in the faith that milk is a too watery food for adults most readers will be surprised to read that "The proportion of protein in milk ( $3 \frac{1}{2}-4$ per cent.) is admittedly very much more than is required in an ordinary adult diet." Of course, this paradoxical statement is false, since the average adult diet, allowing for watery content, is about fifty ounces of foodstuffs, and so, to yield $3 \frac{1}{2}$ to 4 ounces of protein, must contain for the whole of it, 7 to 8 per cent. of protein; the average being obtained from mixing beef steak, chops, ham, all 17-19 per cent. of protein, with potatoes, cabbage, carrot, butter, apples, etc., all 1-2 per cent. protein, and adding some bread, 9 per cent.; egg, 15 per cent.; cheese, 26 per cent.; sugar and starch, nil per cent.; etc., etc.

The whole volume is an excellent and varied feast or diet, highly recommended for study in measured amounts, daily or weekly.

\section{THE DIAGNOSIS OF NERVOUS DISEASES.}

By Sir James Purves-Stewart, K.C.M.G., C.B., M.D., F.R.C.P. Edward Arnold \& Co. 1937. Price 35/-.

This book must have been the vade mecum of legions of students, housephysicians and doctors in acquiring an understanding, and a facility in the diagnosis of nervous diseases, proof of which is surely amply revealed by the fact that it has passed through eight editions in the space of thirty years. When the book made its first appearance in 1906 it was hailed 
with delight and relief, for it taught for the first time the correct appreciation of disease of the nervous system from the disturbance of function and how the particular situation and nature of the diseased process was to be arrived at from the observation and correlation of the symptoms. Since that time each new edition has recorded the steady progress in our knowledge of this field of medicine and the application of the newer developments in technique as employed in the clinical investigation of a case of disease of the nervous system. In this latter field the present edition deserves special mention for the chapter on the examination of the cerebro-spinal fluid, and the portions dealing with the use of air (encephalography), and of radio-opaque substances introduced into the circulation and the ventricular system in the diagnosis of cerebral disease, and particularly cerebral tumours. Another feature of the book which is worthy of special remark is the profusion of well chosen and beautifully reproduced illustrations.

\section{DIAGNOSIS OF SOME DELUSIONAL INSANITY TYPES IN GENERAL PRACTICE.}

By Edwin Hopewell Ash, M.D., Lond. John Bale, Sons \& Danielsson. 1936. Price 2/6.

This compact monograph is written for the use of the medical practitioner. Emphasis is given to the importance of treating psychotic patients at an early stage of schizophrenia. The writer points out quite rightly that delusional patients are not necessarily hallucinated in the early stages of these malignant reaction-types.

The writer exemplifies the different types of Schizophrenics by summarizing concrete cases which he has personally observed in his practice.

\section{Miscellaneous.}

This Section deals with New Drugs, Preparations, Surgical Instruments, etc. The description of each article is supplied by the Producer. Particulars regarding insertions, which are free of cost, may be obtained from the Business Manager, Fellowship of Medicine and Post-Graduate Journal, 519, Grand Buildings, W.C.2.

The Armour Laboratories announce the introduction of two additional preparations to the "Glanoid" range of $\begin{array}{cl}\begin{array}{c}\text { Armour and } \\ \text { Co. Ltd. }\end{array} & \text { Medicinal Primal Origin. }\end{array}$

Concentrate Capsules.

\section{1. "Glanoid" Suprarenal}

$$
\text { 2. "Glanoid" "Salfel " (Enteric }
$$

Coated Bile Salts) Tablets.

"GLANOID" SUPRARENAL CONCENTRATE CAPSULES contain that fraction, extracted from Suprarenal tissue, which possesses therapeutic properties in the treatment of certain allegeric manifestations and also in treating œdema of unknown ætiology.

Clinical experience has revealed that the concentrate has remarkable power to ameliorate symptoms associated with these allergic conditions. The concentrate aids in the control of the water and sodium chloride balance of the extra-cellular body fluids and some evidence is being accumulated which indicates an effect also on the sugar tolerance of allergic individuals.
" Glanoid " Suprarenal Concentrate Capsules will be found to be of value in combating œdema of allergic origin, Hay Fever, Urticaria, Asthma and Migraine.

The dose varies but as a rule one or two Grain 2 capsules after meals is sufficient.

Supplied in Grain 2 capsules. Bottles of 25 - 7s., 50 - 12s. 6d., 100 - 21s.

" GLANOID " “SALFEL " TABLETS contain Sodium Glycocholate and Sodium Taurocholate in the proportion existing in fresh bile. Owing to the bitter taste and specific action of Bile Salts in the intestine, the tablets are supplied in 1 and 3 Grain Enteric Coated tablets.

Bile Salts medication is indicated in a variety of conditions in which there is a diminution in the amount of bile in the intestinal tract. Bile Salts assist both pancreatic digestion and normal peristalsis and provide a powerful stimulant to the secretory activity of the liver.

"Salfel " is supplied in bottles of 100 tablets 1 Grain $5 \mathrm{~s}$. 6d. and 3 Grains $8 \mathrm{~s}$. 6d. 